\title{
Investigation of heavy metals accumulation in the soil and pine trees
}

\author{
Javad Kharkan $^{\mathbb{D}}$, Mohammad Hossein Sayadi ${ }^{* \mathbb{D}}$, Mohammad Reza Rezaei ${ }^{\mathbb{D}}$ \\ Department of Environmental Sciences, School of Natural Resources and Environment, University of Birjand, Birjand, Iran
}

\begin{abstract}
Background: Human activities related to workshops in the cities contribute to the release of heavy metals into the environment, which pose serious risks to the environment and to human health. The aim of the present study was to evaluate the concentration of lead $(\mathrm{Pb})$, iron $(\mathrm{Fe})$, and manganese $(\mathrm{Mn})$ in the pine trees and soil in various land uses of Birjand city, Iran.

Methods: The sampling stations were randomly selected from different land uses including parks, streets, carwashes, car repair shops, and car smooth shops in Birjand city. The pine trees (skin and leaves) and soil samples were collected from 15 stations located at different and uses in 2017. To determine the concentration of heavy metals, atomic absorption spectrometer (Contr AA 700) was used.

Results: It was revealed that the mean concentration of $\mathrm{Pb}, \mathrm{Fe}$ and $\mathrm{Mn}$ in residential soil was 1.79, 419.39, and $30.76 \mathrm{mg} / \mathrm{kg}$, respectively. Moreover, the $\mathrm{Pb}, \mathrm{Fe}$, and $\mathrm{Mn}$ concentration in pine skin and leaves was $0.63-0.18,23.05-9.84$, and $10.05-3.13 \mathrm{mg} / \mathrm{kg}$, respectively. The geo-accumulation index (Igeo) mean of the study areas demonstrated a descending trend for Fe $(16.31 \mathrm{mg} / \mathrm{kg})<\mathrm{Mn}(8.86 \mathrm{mg} / \mathrm{kg})<\mathrm{Pb}(0.41$ $\mathrm{mg} / \mathrm{kg}) . \mathrm{Pb}$ showed the highest transfer factor in the parks and streets followed by $\mathrm{Mn}$ and Fe. In the car repair and smooth shops, the highest transfer factor pertained to $\mathrm{Pb}$ and the lowest one pertained to $\mathrm{Fe}$. The statistical analysis indicated that there was a significant difference in the Fe and Mn concentrations among various land uses $(P<0.05)$.

Conclusion: According to the results, the soils of car repair and smooth shops as well as carwashes in Birjand are becoming polluted by $\mathrm{Pb}, \mathrm{Fe}$, and $\mathrm{Mn}$. Although, it does not threaten the city ecosystem, but with passage of time, these measures will be accumulated due to the soil alkalinity and will reach critical levels.

Keywords: Lead, Iron, Manganese, Soil, Cities

Citation: Kharkan J, Sayadi MH, Rezaei MR. Investigation of heavy metals accumulation in the soil and pine trees. Environmental Health Engineering and Management Journal 2019; 6(1): 17-25. doi: 10.15171/ EHEM.2019.03.
\end{abstract}

Article History:

Received: 20 October 2018

Accepted: 12 January 2019

ePublished: 28 January 2019

\section{Introduction}

Environmental pollution by heavy metals has become a matter of attention on local, regional, and global scales due to their toxicity effects (1-3). Essential metals such as iron $(\mathrm{Fe})$ and manganese $(\mathrm{Mn})$ play a role in metabolic activity and are required for growth, development, and maintenance of body, but high concentrations of these metals have adverse health effects on different organs such as liver, heart, endocrine glands, and neurotoxic effect on the brain $(4,5)$. In contrast, the non-essential metals such as lead $(\mathrm{Pb})$ has no role in metabolic activities of organisms but at low concentrations, it has the potential to affect toxicity on different tissues of living organisms $(6,7) . \mathrm{Pb}$ exposure can cause different health problems such as anemia, bone, renal, reproductive, nervous system disorders, neurohematological damages, and cancers (8).
The urban soil is the most important part of an urban environment. Various studies have been conducted in many countries to investigate the soil contamination by heavy metals $(\mathrm{Pb}, \mathrm{Fe}$, and $\mathrm{Mn})$ in urban soils, and it was revealed that heavy metals concentrations were affected by several factors such as traffic activities, parks, and various workshops $(9,10)$. Human activities related to workshops in the cities contribute to the release of heavy metals into the environment, which pose serious risks to the environment and human health. Brake wear, and exhaust gas are the most important sources for releasing of $\mathrm{Pb}$ from vehicles (11). The levels of soil contamination and plant species are two main factors that affect the dynamics of heavy metals in plant-soil interactions (12). The roadside plants' leaves or stems may also absorb heavy metals through atmospheric deposit or road runoff $(13,14)$. 
Different parts of the plant contain different amounts of heavy metals, so that the highest concentrations of metals are found in roots, stems, and leaves (15).

Some trees such as pine have been used as biological indicators for monitoring heavy metals in the environmental pollution, because these trees are extensively dispersed in most cities as the main plant species with long lifetime (16). It is interesting to note that the dominant treesin the city of Birjand is the pine trees. The vehicles, carwashes, car smooth units, and car repair shops release heavy metals in the urban environment. Since, there has not been a study on the concentration of heavy metals in pine trees (skin and leaves) in the climatic conditions of the region and different land uses, therefore, this study aimed to determine the concentration of $\mathrm{Pb}, \mathrm{Fe}$, and $\mathrm{Mn}$ in the soil and pine trees at different land uses in Birjand city such as different parks, streets, carwashes, car repair shops, and car smooth shops.

\section{Materials and Methods}

Study area

Birjand city is the capital of South Khorasan province in the eastern part of Iran. Birjand city lies on the border with Afghanistan and it is about $1491 \mathrm{~m}$ from the sea level. At 2016 census, its population was 221756 consisting 60240 families. This city is located at a latitude of $32^{\circ} 87^{\prime} \mathrm{N}$ and longitude of $59^{\circ} 21^{\prime} \mathrm{E}$ with cold semi-arid climates (Figure 1). Moreover, Birjand city from the middle of April to December has a dry season with $171 \mathrm{~mm}$ rainfall and 255 sunny days in the year (17).

\section{Sampling and laboratory analysis}

The total of 15 soil and pine trees (skin and leaf) samples were randomly collected from different land uses in Birjand city such as car repair and smooth shops, carwashes, streets, and parks with three replicates and transferred to the Central Laboratory of Environmental Pollutants of Birjand University. The $\mathrm{pH}$ of soil saturation extract was analyzed using a $\mathrm{pH}$ meter. Electrical conductivity (EC) of soil and soil texture was determined by an EC meter and hydrometer method, respectively (18). To measure $\mathrm{pH}, 5 \mathrm{~g}$ of each soil sample was placed into a $50 \mathrm{cc}$ Erlenmeyer flask. Distilled water was added to the sample (1:25 dilution) and kept for 12 hours at ambient temperature. Then, $\mathrm{pH}$ was measured by the $\mathrm{pH}$ meter. Moreover, to determine the EC, $150 \mathrm{~g}$ of the screened soil ( $2 \mathrm{~mm}$ ) was poured into a container and saturated with $150 \mathrm{~mL}$ distilled water (1:1). After saturation, its extract was obtained by Bacchini funnel. A filter paper was placed into the funnel and an extraction glass was kept under the funnel. The extracted soil was collected in the extraction glass. The physiochemical characteristics of the extracted soil samples were reported in Table 1.

\section{Determination of the heavy metals concentration}

To determine the concentration of heavy metals, $1 \mathrm{~g}$ of soaked and sieved soil was placed in an Erlenmeyer flask, then $16 \mathrm{cc}$ acid [a mixture of $4 \mathrm{cc}$ nitric acid (65\%) and $12 \mathrm{cc}$ hydrochloric acid (37\%)] was added to the flask. For acid digestion, the flask was placed on the sand bath at $100^{\circ} \mathrm{C}$ for 6 to 7 hours. At the specified time period, 4 cc per chloric acid was added to the flask placed on the sand bath. After evaporation of $3 \mathrm{cc}$ acid, the sample was flattened by a plastic funnel on the filter paper $(18,19)$.

Determination of heavy metals concentration in pine trees To determine heavy metals concentration in the plant texture, the samples were dried in an oven at $70^{\circ} \mathrm{C}$ for 48 hours, then, the samples were ground by a Chinese oven for better dissolving in the acid, finally, $1 \mathrm{~g}$ of the sample was placed into an Erlenmeyer flask for sample digestion. For chemical digestion of the samples, nitric acid $\left(\mathrm{HNO}_{3}\right)$

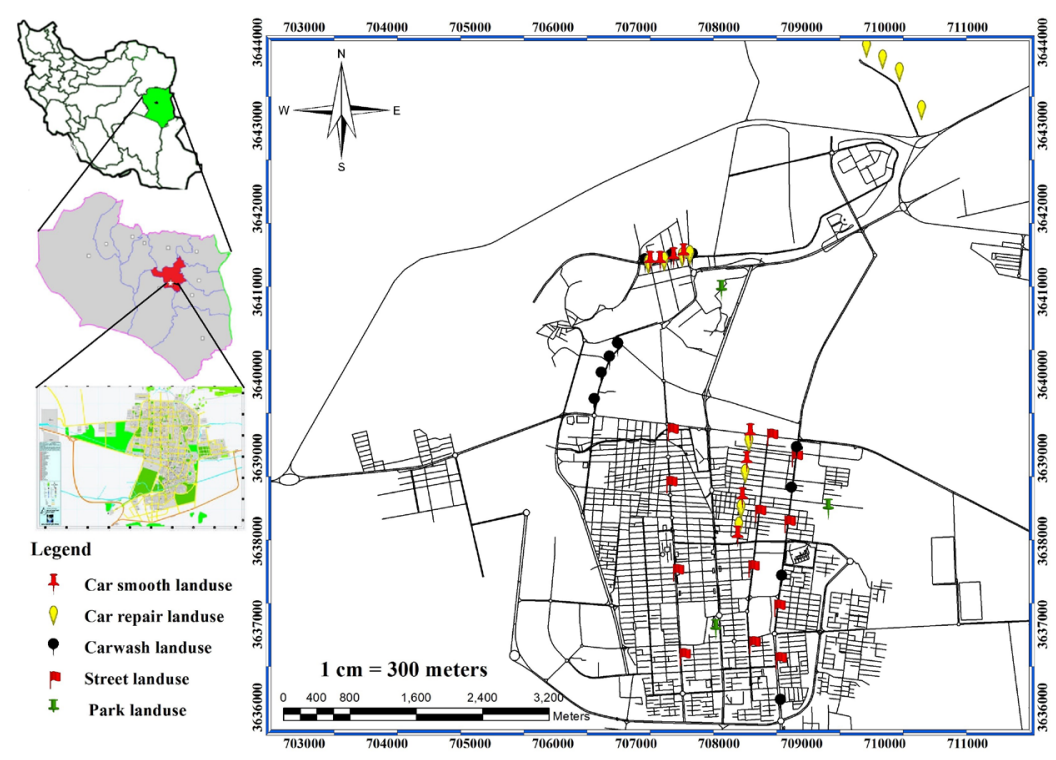

Figure 1. Sampling site map in different parts of Birjand city in eastern Iran. 
Table 1. Physiochemical characteristics of the studied soil samples

\begin{tabular}{lll}
\hline Land Use & pH Soil & Soil EC (MSCM-1) \\
\hline Park & 7.73 & 2.165 \\
Street & 7.43 & 6.67 \\
Carwash & 7.5 & 5.38 \\
Car repair shop & 8.5 & 4.98 \\
Car smooth shop & 8.2 & 6.76 \\
\hline
\end{tabular}

$65 \%$ and per chloric acid 70\%-72\% (5:1.5) were used, the samples were then placed on the sand bath at $100^{\circ} \mathrm{C}$ and heated until the color of the solution was clear. After digestion, the samples were placed at room temperature for cooling, then, the samples were diluted to $50 \mathrm{cc}$ with double distilled water and flattened by filter paper (20). Finally, the samples were analyzed by graphite furnace atomic absorption spectroscopy (ContrAA 700) (with a stock concentration of $1 \mathrm{mg} / \mathrm{mL}$ and compute calibration adjusted $\mathrm{R}^{2}=0.99$ ). The detection limits for each metal were as follows: $\mathrm{Pb}=0.03, \mathrm{Mn}=0.10$, and $\mathrm{Fe}=0.11$, and mean recovery of $98.4,97.8$, and $96 \%$, respectively, were obtained.

\section{Geo-accumulation index}

Geo-accumulation index (Igeo) was used to evaluate soil pollution by comparing the current heavy metals concentration in the soil with their pre-industrial/ background concentration. This index is used to determine the pollution degree and the amount of human factors affecting the soil and sediment (21) and is evaluated through Eq. (1):

$$
\text { Igeo }=\log _{2}\left[\frac{C_{n}}{1.5 B_{n}}\right]
$$

where $C_{n}$ is the measured concentration of element in the sample and $B_{n}$ is the concentration of the same element in the sample. To correct the effects of soil material through human activities, the correction coefficient of 1.5 was used. According to this index, the soils are categorized into 7 different groups as below (22).

Igeo $\leq 0$ (non-contaminated), $1<$ Igeo $<0$ (noncontaminated to slightly infected), $2<$ Igeo $<1$ (slightly infected), $3<$ Igeo $<2$ (slightly infected to very polluted), $4<$ Igeo $<3$ (very polluted), $5<$ Igeo $<4$ (very polluted to severely infected), and $5 \leq$ Igeo (severely infected).

\section{Contamination factor index}

According to contamination factor (CF) index, the enrichment of metals in relation to the background concentrations can be evaluated and the degree of soil pollution can be determined (23). The contamination factor is determined using Eq. (2):

$\mathrm{CF}=[\mathrm{C}]$ sample $/[\mathrm{C}]$ background
Where $C F$ is contamination factor, $(C)$ sample is the concentration of considered element, and $(C)$ background is the concentration of basic element in the sample. In terms of contamination by heavy metals, soils are divided into 4 groups based on the contamination factor. $1>\mathrm{CF}$ (lowly polluted), $3<\mathrm{CF}<1$ (moderately polluted), $6 \leq \mathrm{CF}<3$ (highly polluted), and $6 \leq \mathrm{CF}$ polluted) $(24,25)$. In this study, the sample was collected from the control soil (i.e. an area without any human activity) and from the depth of one and a half meters. The background concentration of $\mathrm{Pb}, \mathrm{Fe}$, and $\mathrm{Mn}$ was $0.26,305.4$, and 23.94, respectively.

\section{Pollution load index}

To evaluate the severity of contamination, the pollution load index (PLI) was used. Using PLI, the effects of total contamination by different metals is evaluated. The advantage of PLI over other indicators is that the pollution risk index of all the studied metals is determined in the area. According to this index, the standardized quality of soil is divided into 5 levels (26).

Highly polluted $(\mathrm{P} \leq 0.7)$, clean contaminated $(0.7<\mathrm{P} \leq$ $1)$, slightly polluted $(1<\mathrm{P} \leq 2)$, moderately $\operatorname{polluted}(2<\mathrm{P}$ $\leq 3)$, and highly polluted $(\mathrm{P}>3)$.

The pollution coefficient of $\mathrm{Pb}$ is evaluated based on the Eq. (3):

$P L I=\sqrt[n]{C F 1 \times C F 2 \times C F 3 \times \ldots \times C F n}$

\section{Enrichment factor}

The evaluation of the soils pollution was made by using enrichment factor to overcome the difficulties in making an overall assessment of the degree of metal contamination in soils. This factor is evaluated based on the Eq. (4)(27).

$E F=\frac{\left[\frac{C x}{C r e f}\right] \text { Sample }}{\left[\frac{C x}{C r e f}\right] \text { Background }}$

Where $E F$ is enrichment factor, $C_{x}$ is the concentration of measured element in the sample, and $C_{r e f}$ is the concentration of the reference element $(\mathrm{Fe})$. The reference element is an element that has the geological origin. In the environmental studies, $\mathrm{Sr}, \mathrm{Al}, \mathrm{Fe}, \mathrm{Ti}$, and $\mathrm{Zr}$ are usually used as the reference elements (28). The degree of heavy metals pollution can be divided into 5 groups (29): EF < 2 (low pollution level), $2 \leq \mathrm{EF}<5$ (moderate pollution level), $5 \leq \mathrm{EF}<20$ (high pollution level), $20 \leq \mathrm{EF}<40$ (very high pollution level), and $40 \leq \mathrm{EF}$ (severe pollution level).

\section{Potential ecological risk}

The index of potential ecological risk (Er) is used to evaluate the environmental potential risks of metals in the soil (30). In this study, the potential Er of heavy metals was determined using the following equations: 


$$
C_{j}^{i}=C^{i} / C_{j}^{i} E r=T_{n}^{i} \times C_{j}^{i}
$$

Where $C^{i}$ is the concentration of measured metal in studied soil sample, $C_{j}^{i}$ is the reference of background value from this element, and $T_{n}^{i}$ is the toxicity index of the heavy metal (Pb:5) (31). Er shows the potential ecological risk of $\mathrm{Pb}$. The pollution level is divided into 5 levels based on the ecological risk. Er $<40$ (low potential Er), $40 \leq$ $\mathrm{Er}<80$ (moderate potential $\mathrm{Er}$ ), $80 \leq \mathrm{Er}<160$ (significant potential Er), $160 \leq \mathrm{Er}<320$ (high potential Er), $320 \leq \mathrm{Er}$ (very high potential Er).

\section{Transfer factor of heavy metals}

Transfer factor is described as the ratio of metal concentration in tree organ $\left(C_{\text {part of tree }}\right)$ and concentration of the same metal in the soil $\left(C_{\text {soil }}\right)(32)$. This factor is used to measure the capability of the tree to absorb the metal from the soil and is evaluated based on the Eq. (6):

$T F=C_{\text {Part of tree }} / C_{\text {soil }}$

\section{Statistical analysis}

Data were analyzed using SPSS version 20. The concentrations of heavy metals $(\mathrm{Pb}, \mathrm{Mn}$, and $\mathrm{Fe}$ ) in soil and pine's skin and leaf were compared in different stations using one-way analysis of variance (ANOVA). Moreover, the Pearson correlation coefficient was used to assess the relationship among heavy metals in the soil of the study area. Data were expressed as mean \pm standard deviation (mean \pm SD).

\section{Results}

The solubility of heavy metals to dissolve and their access to plants depend on the physicochemical characteristics of the soil (e.g. acidity and texture) that are considered essential among the effective factors used in plants to absorb the heavy metals. Nevertheless, soil is usually considered as the most important factor (33). Mean $\mathrm{pH}$ of 7.87 represents an alkaline condition for all soil samples (Table 1). Effectually, with increasing $\mathrm{pH}$, the access level to heavy metals decreases, so its concentration increases in the soil.
The average concentration of heavy metals $\mathrm{Pb}, \mathrm{Fe}$, and $\mathrm{Mn}$ was measured by atomic absorption spectrophotometer (AAS) in soil and pine trees (skin and leaf) in different land uses (Table 2). The average concentration of $\mathrm{Pb}, \mathrm{Fe}$, and $\mathrm{Mn}$ was $0.87,150.79$, and $14.65 \mathrm{mg} / \mathrm{kg}$, respectively. The statistical analysis indicated that there are significant differences in $\mathrm{Pb}$ concentration in the soil and pine's skin among various land uses $(P>0.05)$. Also, there was a significant difference in the Fe concentration in pine's skin and leaf $(P<0.01)$. There were significant differences in $\mathrm{Mn}$ concentration in the soil and pine's skin $(P<0.01)$. The average concentration of $\mathrm{Pb}, \mathrm{Fe}$, and $\mathrm{Mn}$ in the soil was $1.79,419.39$, and $30.75 \mathrm{mg} / \mathrm{kg}$, respectively. The average concentration of $\mathrm{Pb}, \mathrm{Fe}$, and $\mathrm{Mn}$ in the pine's skin and leaf was $0.63,23.04$, and $10.06 \mathrm{mg} / \mathrm{kg}$ and 0.17 , 9.84 , and $3.14 \mathrm{mg} / \mathrm{kg}$, respectively. It is clear that, the concentration of these metals in different parts of pine exhibited a descending order of leaf $<$ skin $<$ soil.

The highest concentration of $\mathrm{Pb}$ belonged to car repair shop and the amount of $\mathrm{Pb}$ in different land uses was in a descending order of Park < Street $<$ Car smooth shop $<$ Carwash $<$ Car repair shop. So, carwash and car repair shop significantly increased $\mathrm{Pb}$ in the urban environment. $\mathrm{Pb}$ had the highest concentration $(4.56 \mathrm{mg} / \mathrm{kg})$ in car repair shop and the lowest one in park (0.28). Fe and Mn in park demonstrated the highest concentration. $\mathrm{Pb}, \mathrm{Fe}$, and Mn showed the highest concentration in the soil and their concentration in pine's skin was more than the leaf. The statistical analysis showed that there are significant differences in $\mathrm{Pb}$ and $\mathrm{Mn}$ concentration in the soil and pine's skin among different land uses $(P<0.01)$. Also, there was a significant difference in the Fe concentration in pine's leaf among different land uses $(P<0.01)$.

The results of Pearson correlation coefficient showed that there was a strong correlation between the studied elements (Table 3). Strong correlation was observed between the elements that were contaminated from the common sources like wastes from car wash and repair or through soil materials. In a similar study, Bhuiyan et al evaluated the correlation of heavy metals by Pearson correlation coefficient and concluded that the metals that showed high correlation, probably had the same pollution

Table 2. The mean $( \pm \mathrm{SD})$ of heavy metals $(\mathrm{Mn}, \mathrm{Fe}$, and $\mathrm{Pb})$ in the soil and pine tree (skin and leaf) in different land uses $(\mathrm{mg} / \mathrm{kg})$

\begin{tabular}{|c|c|c|c|c|c|c|c|c|c|}
\hline \multirow{2}{*}{ Land use } & \multicolumn{3}{|c|}{$M n$} & \multicolumn{3}{|c|}{$\mathrm{Fe}$} & \multicolumn{3}{|c|}{$\mathrm{Pb}$} \\
\hline & Leaf & Skin & Soil & Leaf & Skin & Soil & Leaf & Skin & Soil \\
\hline Park & $2.44 \pm 1.66$ & $23.81 \pm 3.91$ & $42.77 \pm 3.14$ & $15.54 \pm 1.16$ & $53.2 \pm 7.99$ & $478.8 \pm 73.83$ & $0.15 \pm 0.40$ & $0.45 \pm 0.08$ & $0.28 \pm 0.07$ \\
\hline Street & $2.03 \pm 0.31$ & $11.86 \pm 1.25$ & $22.8 \pm 3.24$ & $9.19 \pm 0.82$ & $21.02 \pm 14.23$ & $441.5 \pm 75.23$ & $0.11 \pm 0.02$ & $0.66 \pm 0.09$ & $0.37 \pm 0.05$ \\
\hline Carwash & $2.81 \pm 0.54$ & $4.26 \pm 0.30$ & $27.21 \pm 1.28$ & $9.16 \pm 0.92$ & $15.83 \pm 1.89$ & $480.9 \pm 51.16$ & $0.14 \pm 0.06$ & $0.18 \pm 0.06$ & $2.05 \pm 0.43$ \\
\hline Car repair shop & $4.62 \pm 0.40$ & $6.07 \pm 2.72$ & $24.21 \pm 4.02$ & $6.55 \pm 1.02$ & $14.08 \pm 2.86$ & $345.6 \pm 90.24$ & $0.25 \pm 0.15$ & $0.87 \pm 0.19$ & $4.56 \pm 1.37$ \\
\hline $\begin{array}{l}\text { Car smooth } \\
\text { shop }\end{array}$ & $3.82 \pm 0.60$ & $4.28 \pm 1.06$ & $36.8 \pm 10.29$ & $8.76 \pm 0.81$ & $10.75 \pm 4.35$ & $350.1 \pm 64.59$ & $0.22 \pm 0.09$ & $0.99 \pm 0.67$ & $1.68 \pm 1.31$ \\
\hline$F$ value & 4.57 & 7.80 & 40.43 & 11.94 & 3.07 & 1.28 & 2.59 & 15.32 & 36.89 \\
\hline$P$ value & 0.23 & 0.004 & 0.001 & 0.001 & 0.068 & 0.34 & 0.10 & 0.001 & 0.001 \\
\hline
\end{tabular}


Table 3. The Pearson correlation among metal concentrations ( $\mathrm{Pb}, \mathrm{Fe}$, and $\mathrm{Mn})$ in soil

\begin{tabular}{lccc}
\hline & $\mathrm{Pb}$ & $\mathrm{Fe}$ & $\mathrm{Mn}$ \\
\hline $\mathrm{Pb}$ & 1 & & \\
$\mathrm{Fe}$ & $0.441^{* *}$ & 1 & \\
$\mathrm{Mn}$ & $0.316^{*}$ & $0.832^{* *}$ & 1 \\
\hline
\end{tabular}

*At 95\% level is significant; **At $99 \%$ level is significant.

sources (26).

Geo-accumulation index

According to Table 4, the mean of Igeo of the study areas exhibited a increasing order of Igeo $\mathrm{Pb}(0.41)<$ Igeo $\mathrm{Mn}$ (8.86)<Igeo Fe (16.31). As shown in this table, the Igeo value of both elements $\mathrm{Fe}$ and $\mathrm{Mn}$ was over 5, therefore, the area is very heavily polluted.

\section{Contamination factor}

The $\mathrm{CF}$ of $\mathrm{Pb}$ showed low (12.5\%), moderate (31.25\%), high $(6.26 \%)$, and severe pollution (50\%). Furthermore, Fe and Mn exhibited low (18.75\%) and moderate pollution (81.25\%), respectively (Table 5). As shown in Table 4 , the CF mean in the study areas showed a increasing order of $\mathrm{Mn}(1.27)<\mathrm{Fe}(1.35)<\mathrm{Pb}(6.50)$.

\section{Enrichment factor}

The enrichment factor (EF) average for the studied heavy metals in the soil samples showed a descending order of $\mathrm{Mn}(1.27)<\mathrm{Fe}(1.35)<\mathrm{Pb}(6.51)$, therefore, the enrichment factor average for $\mathrm{Pb}$ was more than 1.5 (Table 6).

\section{Potential ecological risk}

In this study, the potential ecological risk (Er) for $\mathrm{Pb}$ was evaluated. The values of potential Er are presented in Table

Table 4. Descriptive statistical analyses of accumulation land index (Igeo) and contamination factor (CF) of the studied metals

\begin{tabular}{lcccc}
\hline Parameter & Mean & Maximum & Minimum & SD \\
\hline Igeo $\mathrm{Pb}$ & 0.41 & 4.68 & 0.08 & 1.65 \\
Igeo $\mathrm{Fe}$ & 16.31 & 16.77 & 15.82 & 0.32 \\
Igeo $\mathrm{Mn}$ & 8.86 & 9.48 & 8.31 & 0.4 \\
$\mathrm{CF} \mathrm{Pb}$ & 6.5 & 23.42 & 0.87 & 6.73 \\
$\mathrm{CF} \mathrm{Fe}$ & 1.35 & 1.8 & 0.93 & 0.29 \\
$\mathrm{CF} \mathrm{Mn}$ & 1.27 & 1.86 & 0.83 & 0.38 \\
\hline
\end{tabular}

Table 5. The contamination factor ( $\mathrm{CF}$ ) of heavy metals ( $\mathrm{Pb}, \mathrm{Fe}$, and $\mathrm{Mn}$ ) in the soil of different land uses

\begin{tabular}{lcccc}
\hline Metal & $\begin{array}{c}\text { Very high } \\
\text { pollution }\end{array}$ & $\begin{array}{c}\text { High } \\
\text { pollution }\end{array}$ & $\begin{array}{c}\text { Moderate } \\
\text { pollution }\end{array}$ & Low Pollution \\
\hline $\mathrm{Pb}$ & $50^{*}$ & 6.26 & 31.25 & 12.5 \\
$\mathrm{Fe}$ & 0 & 0 & 81.25 & 18.75 \\
$\mathrm{Mn}$ & 0 & 0 & 81.25 & 18.75 \\
\hline
\end{tabular}

7. The results showed that the average potential $\mathrm{Er}$ for $\mathrm{Pb}$ was 34.36 and its low and significant values were $60 \%$ and $13.3 \%$, respectively (Table 8 ). Thus, $\mathrm{Pb}$ is an effective factor in increasing the potential $\mathrm{Er}$ in the aforementioned and uses soil. This metal, which is found as a colored material and petroleum product and used in the car smooth and repair shop, is very dangerous.

\section{Transfer factor}

Transfer factor of the studied heavy metals in the soil and pine's skin and leaf is shown in Table 9. $\mathrm{Pb}$ showed the highest transfer factor in the parks and streets followed by $\mathrm{Mn}$ and $\mathrm{Fe}$. In carwash, the transfer factor demonstrated a descending order of $\mathrm{Fe}<\mathrm{Pb}<\mathrm{Mn}$. In the car repair and smooth shops, the highest transfer factor pertained to $\mathrm{Pb}$ and the lowest one to Fe. High value of transfer factor of $\mathrm{Pb}$ signifies high ability of pine to absorb $\mathrm{Pb}$ from the soil. In several plants, the concentration of $\mathrm{Pb}$ was hundred times more than the permissible limits of its accumulation in the plant.

\section{Discussion}

Different human activities like car workshops can cause soil pollution that leads to major environmental problems. After a long time, heavy metals can accumulate in the human body. The bivalent $\mathrm{Pb}$ is replaced in the body, instead of calcium ion, and this replacement permits $\mathrm{Pb}$ to remain in the body for a long time. $\mathrm{Pb}$ accumulation can disrupt the human circulatory system as well as kidneys. It also has serious negative effects on the physical development of children. The reasons for the use of $\mathrm{Pb}$ in car smooth, repair shop, and carwash is that it is one of the petroleum products and its derivatives are used not only in producing various colors, but also for disposal of motor oil from battery water (34). In a study in Kerman city, the most important factors that increase the heavy metals in the soil, especially $\mathrm{Pb}, \mathrm{Zn}$, and $\mathrm{Cu}$, were traffic and its related activities such as gas stations, battery packs, oil changes, and car painting and smooth (35). The results of a study by Saboohi et al showed that the floor dust of Yazd battery factory workshops has high level of heavy metals concentration so that it has the potential environmental and health risks (36). The most dangerous

Table 6. The enrichment factor average for the heavy metals in the soil samples

\begin{tabular}{lll}
\hline $\mathrm{Mn}$ & $\mathrm{Fe}$ & $\mathrm{Pb}$ \\
\hline 1.27 & 1.35 & 6.51 \\
\hline
\end{tabular}

Table 7. The results of statistical analysis of ecological risk (Er) for $\mathrm{Pb}$ in the studied stations

\begin{tabular}{llll}
\hline \multicolumn{4}{c}{ Ecological risk (Er) } \\
\hline Mean & Maximum & Minimum & SD \\
\hline 34.36 & 117.2 & 4.33 & 34.07 \\
\hline
\end{tabular}


Table 8. The results of statistical analysis of ecological risk (Er) for $\mathrm{Pb}$ in the studied stations

\begin{tabular}{lllll}
\hline Very high ecological risk & High ecological risk & Significant ecological risk & Moderate ecological risk & Low ecological risk \\
\hline 0 & 0 & $2(13.3 \%)$ & $4(26.6 \%)$ & $9(60 \%)$ \\
\hline
\end{tabular}

Table 9. Transfer factor of heavy metals (mean $\pm S D$ ) in different land uses

\begin{tabular}{|c|c|c|c|c|c|c|}
\hline \multirow{2}{*}{ Land use } & \multicolumn{2}{|c|}{$\mathrm{TF}_{\mathrm{Mn}}$} & \multicolumn{2}{|c|}{$\mathrm{TF}_{\mathrm{Fe}}$} & \multicolumn{2}{|c|}{$\mathrm{TF}_{\mathrm{Pb}}$} \\
\hline & Leaf & Skin & Leaf & Skin & Leaf & Skin \\
\hline Park & $0.6 \pm 0.4$ & $0.56 \pm 0.6$ & $0.33 \pm 0.05$ & $0.11 \pm 0.01$ & $0.56 \pm 0.7$ & $1.68 \pm 0.1$ \\
\hline Street & $0.93 \pm 0.2$ & $0.52 \pm 0.3$ & $0.2 \pm 0.01$ & $0.46 \pm 0.3$ & $0.33 \pm 0.11$ & $1.87 \pm 0.4$ \\
\hline Carwash & $0.10 \pm 0.2$ & $0.16 \pm 0.05$ & $0.2 \pm 0.01$ & $0.3 \pm 0.01$ & $0.07 \pm 0.2$ & $0.9 \pm 0.1$ \\
\hline Car repair shop & $0.17 \pm 0.2$ & $0.24 \pm 0.07$ & $0.2 \pm 0.01$ & $0.4 \pm 0.01$ & $0.5 \pm 0.01$ & $0.19 \pm 0.2$ \\
\hline Car smooth shop & $0.7 \pm 0.9$ & $0.1 \pm 0.1$ & $0.02 \pm 0.01$ & $0.03 \pm 0.01$ & $0.16 \pm 0.06$ & $0.62 \pm 0.1$ \\
\hline
\end{tabular}

effects pertained to $\mathrm{Fe}, \mathrm{Zn}$, and $\mathrm{Pb}$. The soil and trees near the parks and streets receive $\mathrm{Pb}$ pollution from vehicle gases. Kleckerova and Dočekalova reported that pollution of $\mathrm{Pb}$ and $\mathrm{Ca}$ in Berono's urban areas is due to human activities and urban activities like traffic (37). Yang et al in their study on urban soil found that $\mathrm{Pb}, \mathrm{Ca}$, and $\mathrm{Cu}$ had significant correlation so that the sources of pollution by these metals were traffic and industrial activities (30). The close relationship among heavy metals like $\mathrm{Pb}, \mathrm{Fe}$, and $\mathrm{Mn}$ showing the same sources $(38,39)$. The use of petroleum products and its derivatives such as thinner and use of different colors in car painting as well as disposal of motor oil from battery water are appropriate justifications for high Igeo values of heavy metals in car repair and smooth shops rather than parks and streets. Davashi and Azimzadeh in the study of heavy metals in the soil of refinery near Ghamishloo's shelter found that the use of petroleum products and its derivatives like gasoline are known as an appropriate justification for high value of Igeo $_{\mathrm{Pb}}$ in the soil around the refinery (40). Zhu et al in a study on Igeo index evaluated the degree of heavy metals pollution in the Nanjing's soil-China and categorized $\mathrm{Pb}$, $\mathrm{Zn}$, and $\mathrm{Cu}$ in the uninfected class, and besides, signified the effect of industrialization and urbanization on the degree of heavy metals pollution in the urban soils during the time (41). Therefore, the results of Igeo index showed that the pollution level in the study area was high.

Among aforementioned land uses, the workshop had the maximum share in $\mathrm{Pb}$ dispersion. The contamination factor assessment showed that the soil of workshops and smooth shops demonstrated high and severe pollution for $\mathrm{Pb}$, and low and moderate pollution for Fe and $\mathrm{Mn}$. $\mathrm{Lu}$ et al reported that the highest concentration of $\mathrm{Pb}$ and Mn was observed in the industrial areas and the lowest concentration of these elements was observed in the residential areas with low traffic (42). The enrichment factor average for $\mathrm{Pb}$ was more than 1.5 , which signifies that the source of this metal in the soil was human activities (43). The contamination level of each element in the study areas based on the average of this factor revealed that $\mathrm{Pb}$ had the highest pollution level, whereas Fe and $\mathrm{Mn}$ had the lowest one. In addition, the results showed that $\mathrm{Pb}$ enters the environment through human activities and it does not have a natural origin. Yang et al in their study on urban soils of Chung Chun found that $\mathrm{Pb}, \mathrm{Cu}, \mathrm{Ca}$, and $\mathrm{Hg}$ have significant correlation and identified industrial activities and traffic asthe sources of metals pollution (30). Taghipour et al reported that $\mathrm{Pb}, \mathrm{Zn}$, and $\mathrm{Cu}$, respectively had the highest concentration in urban soil due to industrial activities (44). Therefore, the results are consistent with the results of this study wherein high level of $\mathrm{Pb}$ contamination was found in the soil of carwashes and repair workshops, so it is quite essential to decrease heavy metals levels to inhibit the potential hazards of these metals in the environment. Various studies of ecological risk assessment showed that $\mathrm{Pb}$ caused various diseases in humans like kidney problems, liver diseases, and cancer $(45,46)$. Thus, $\mathrm{Pb}$ can affect the local ecological function in the long run and currently, it does not have the ability to create health and environmental problems (47-49). So, it is important to consider the levels of heavy metals to inhibit the potential hazards of these metals in the environment. The transfer factor shows that pine can be used to refine the polluted areas. Lebeau et al reported that the transfer factor of elements from terrestrial to aerial organs can be used to identify the over accumulated organs (50). Some researchers used the ratio of heavy metals concentration in the aerial part/root to describe the plant resistance and reaction against high levels of metals in the soil wherein this ratio is greater than one in plants containing more than one reagent, and less than one in plants having less than one reagent (51).

\section{Conclusion}

According to the results, the soils of car repair and smooth shops as well as carwashes in Birjand are becoming polluted by $\mathrm{Pb}, \mathrm{Fe}$, and $\mathrm{Mn}$. Although, it does not threaten the city ecosystem, but with passage of time, these measures will be accumulated due to the soil alkalinity and will reach critical levels. The soil and plant surrounding the 
streets and parks are contaminated by $\mathrm{Pb}$ from vehicles gases. Effectually, $\mathrm{Pb}$ concentration in the soil and plant increases with traffic volume and decreases with the distance from the main roads and streets. However, in this study, the contamination factors like accumulation land index and contamination factor were evaluated. The contamination load and enrichment factor showed that $\mathrm{Pb}$ showed moderate to high pollution, whereas Fe and Mn represented low to moderate pollution in the car repair and smooth shops. According to the ecological risk index, $\mathrm{Pb}, \mathrm{Fe}$, and $\mathrm{Mn}$ in the aforementioned land uses doesn't have th eability to create the health and environmental problems. However, to prevent these problems, the potential hazards of these metals in the environment should be considered. In parks and streets, the transfer factor more than 1 signifies the high ability of pine to absorb $\mathrm{Pb}$ from the soil. So, it can be safely concluded that pine can be used to refine the contaminated areas in parks and streets.

\section{Acknowledgements}

This article is a part of a Master's thesis sponsored by Birjand University. The authors would like to gratitude Birjand University for providing access to the laboratory facilities to perform this study.

\section{Ethical issues}

The authors certify that all data collected during the study are as stated in the manuscript, and no data from the study has been or will be published separately elsewhere.

\section{Competing interests}

The authors declare that they have no competing interests.

\section{Authors' contributions}

All authors participated in the data collection, analysis, and interpretation. All authors critically reviewed, refined, and approved the manuscript.

\section{References}

1. Sayadi MH, Rezaei MR, Rezaei A. Fraction distribution and bioavailability of sediment heavy metals in the environment surrounding MSW landfill: a case study. Environ Monit Assess 2015; 187(1): 4110. doi: 10.1007/s10661-014-4110-1.

2. Maleki A, Azadi NA, Mansouri B, Majnoni F, Rezaei Z, Gharibi F. Health risk assessment of trace elements in two fish species of Sanandaj Gheshlagh Reservoir, Iran. Toxicol Environ Health Sci 2015; 7(1): 43-9. doi: 10.1007/s13530015-0219-z.

3. Mansouri B, Salehi J, Etebari B, Moghaddam HK. Metal concentrations in the groundwater in Birjand flood plain, Iran. Bull Environ Contam Toxicol 2012; 89(1): 138-42. doi: 10.1007/s00128-012-0630-y.

4. Gentry PR, Van Landingham C, Fuller WG, Sulsky SI, Greene TB, Clewell HJ 3rd, et al. A tissue dose-based comparative exposure assessment of manganese using physiologically based pharmacokinetic modeling-The importance of homeostatic control for an essential metal. Toxicol Appl Pharmacol 2017; 322: 27-40. doi: 10.1016/j. taap.2017.02.015.

5. Rehman IU, Ishaq M, Ali L, Khan S, Ahmad I, Din IU, et al. Enrichment, spatial distribution of potential ecological and human health risk assessment via toxic metals in soil and surface water ingestion in the vicinity of Sewakht mines, district Chitral, Northern Pakistan. Ecotoxicol Environ Saf 2018; 154: 127-36. doi: 10.1016/j.ecoenv.2018.02.033.

6. Sayadi MH, Torabi S. Geochemistry of soil and human health: a review. Pollut Res 2009; 28(2): 257-62.

7. Li R, Tang C, Cao Y, Jiang T, Chen J. The distribution and partitioning of trace metals $(\mathrm{Pb}, \mathrm{Cd}, \mathrm{Cu}$, and $\mathrm{Zn})$ and metalloid (As) in the Beijiang River. Environ Monit Assess 2018; 190(7): 399. doi: 10.1007/s10661-018-6789-x.

8. Sayadi MH, Rezaei A, Sayyed MR. Grain size fraction of heavy metals in soil and their relationship with land use. Proc Int Acad Ecol Environ Sci 2017; 7(1): 1-11.

9. Saeedi M, Hosseinzadeh M, Jamshidi A, Pajooheshfar SP. Assessment of heavy metals contamination and leaching characteristics in highway side soils, Iran. Environ Monit Assess 2009; 151(1-4): 231-41. doi: 10.1007/s10661-0080264-z.

10. Chen X, Xia X, Zhao Y, Zhang P. Heavy metal concentrations in roadside soils and correlation with urban traffic in Beijing, China. J Hazard Mater 2010; 181(1-3): 640-6. doi: 10.1016/j.jhazmat.2010.05.060

11. Yan X, Zhang F, Zeng C, Zhang M, Devkota LP, Yao T. Relationship between heavy metal concentrations in soils and grasses of roadside farmland in Nepal. Int J Environ Res Public Health 2012; 9(9): 3209-26. doi: 10.3390/ ijerph9093209.

12. Hasanvand H, Ghasemi Aghbash F, Solgi E, Pazhohan I. The distance from road effects on heavy metals accumulation in soil and leaves of Persian oak trees (Quercusbrantii) in Aleshtar- Khorramabad highway. Journal of Forest Research and Development 2018; (4)1: 29-41. [In Persian].

13. BiX, Ren L, Gong M,HeY,WangL,MaZ. Transfer of cadmium and lead from soil to mangoes in an uncontaminated area, Hainan Island, China. Geoderma 2010; 155(1-2): 115-20. doi:10.1016/j.geoderma.2009.12.004.

14. Carrero JA, Goienaga N, Barrutia O, Artetxe U, Arana G, Hernandez A, et al. Diagnosing the impact of traffic on roadside soils through chemometric analysis on the concentrations of more than 60 metals measured by ICP/ MS. In: Rauch S, Morrison GM, Monzón A, eds. Highway and Urban Environment. Dordrecht: Springer; 2010. p. 329-36. doi: 10.1007/978-90-481-3043-6_35.

15. Mirecki N, Agic R, Sunic L, Milenkovic L, Ilic ZS. Transfer factor as indicator of heavy metals content in plants. Fresen Environ Bull 2015; 24(11c): 4212-9.

16. Miri M, Ehrampoush MH, Ghaffari HR, Ebrahimi Aval $\mathrm{H}$, Rezai M, Najafpour F, et al. Atmospheric heavy metals biomonitoring using a local Pinus eldarica tree. Health Scope 2017; 6(1): e39241. doi: 10.17795/jhealthscope-39241.

17. Sayadi MH, Sayyed MR, Saptarshi PG. An assessment of the Chitgar river sediments for the short-term accumulation of the heavy metals ( $\mathrm{Cr}, \mathrm{Co}, \mathrm{Cd}, \mathrm{Cu}, \mathrm{Pb}, \mathrm{Ni}$ and $\mathrm{Zn}$ ) from Tehran, Iran. Pollut Res 2008; 27(4): 627-34.

18. Sayadi MH, Rezaei MR, Rezaei A. Sediment toxicity and 
ecological risk of trace metals from streams surrounding a municipal solid waste landfill. Bull Environ Contam Toxicol 2015; 94(5): 559-63. doi: 10.1007/s00128-015-1518-4.

19. Huang SW, Jin JY. Status of heavy metals in agricultural soils as affected by different patterns of land use. Environ Monit Assess 2007; 139(1-3): 317. doi: 10.1007/s10661-0079838-4.

20. Whole Building Design Guide (WBDG). EPA 600/4-79020 methods for chemical analysis of water and wastes. [cited 2018 Oct 2] Available from: https://www.wbdg.org/ $\mathrm{ffc} /$ epa/criteria/epa-600-4-79-020.

21. Shi G, Chen Z, Bi C, Li Y, Teng J, Wang L, et al. Comprehensive assessment of toxic metals in urban and suburban street deposited sediments (SDSs) in the biggest metropolitan area of China. Environ Pollut 2010; 158(3): 694-703. doi: 10.1016/j.envpol.2009.10.020.

22. Odewande AA, Abimbola AF. Contamination indices and heavy metal concentrations in urban soil of Ibadan metropolis, southwestern Nigeria. Environ Geochem Health 2008; 30(3): 243-54. doi: 10.1007/s10653-007-91122.

23. Naimi S, Ayoubi S. Vertical and horizontal distribution of magnetic susceptibility and metal contents in an industrial district of central Iran. J Appl Geophy 2013; 96: 55-66. doi: 10.1016/j.jappgeo.2013.06.012.

24. Rashed MN. Monitoring of contaminated toxic and heavy metals, from mine tailings through age accumulation, in soil and some wild plants at Southeast Egypt. J Hazard Mater 2010; 178(1-3): 739-46. doi: 10.1016/j.jhazmat.2010.01.147.

25. Islam S, Ahmed K, Al-Mamun H, Hoque F. Preliminary assessment of heavy metal contamination in surface sediments from a river in Bangladesh. Environ Earth Sci 2015; 73(4): 1837-48. doi: 10.1007/s12665-014-3538-5.

26. Bhuiyan MA, Parvez L, Islam MA, Dampare SB, Suzuki S. Heavy metal pollution of coal mine-affected agricultural soils in the northern part of Bangladesh. J Hazard Mater 2010; 173(1-3): 384-92. doi: 10.1016/j.jhazmat.2009.08.085.

27. Huang $\mathrm{P}, \mathrm{Li}$ TG, Li AC, Yu XK, Hu NJ. Distribution, enrichment and sources of heavy metals in surface sediments of the North Yellow Sea. Cont Shelf Res 2014; 73 : 1-13. doi: 10.1016/j.csr.2013.11.014.

28. Abrahim GM, Parker RJ. Assessment of heavy metal enrichment factors and the degree of contamination in marine sediments from Tamaki Estuary, Auckland, New Zealand. Environ Monit Assess 2008; 136(1-3): 227-38. doi: 10.1007/s10661-007-9678-2.

29. Li X, Feng L. Multivariate and geostatistical analyzes of metals in urban soil of Weinan industrial areas, Northwest of China. Atmos Environ 2012; 47: 58-65. doi: 10.1016/j. atmosenv.2011.11.041.

30. Yang Z, Lu W, Long Y, Bao X, Yang Q. Assessment of heavy metals contamination in urban topsoil from Changchun City, China. J Geochem Explor 2011; 108(1): 27-38. doi: 10.1016/j.gexplo.2010.09.006.

31. Lu A, Wang J, Qin X, Wang K, Han P, Zhang S. Multivariate and geostatistical analyses of the spatial distribution and origin of heavy metals in the agricultural soils in Shunyi, Beijing, China. Sci Total Environ 2012; 425: 66-74. doi: 10.1016/j.scitotenv.2012.03.003.

32. Bose S, Jain A, Rai V, Ramanathan AL. Chemical fractionation and translocation of heavy metals in Canna indica L. grown on industrial waste amended soil. J Hazard Mater 2008; 160(1): 187-93. doi: 10.1016/j. jhazmat.2008.02.119.

33. Erfanmanesh M, Afyuni M. Environmental Pollution Water, Soil and Air. Esfahan: Arkan; 2005. [In Persian].

34. Kreith F, Tchobanoglous G. Handbook of Solid Waste Management. 2nd ed. New York: McGraw-Hill Education; 2002.

35. HamzehMA, Mirzaee M, Mozaffari H. Concentrations of $\mathrm{Pb}, \mathrm{Zn}, \mathrm{Cu}$ and $\mathrm{Cd}$ and their distribution in the urban environment of Kerman, Iran. Journal of Environmental Science and Technology 2009; 11(3): 161-77. [In Persian].

36. Sabouhi M, Nejadkoorki F, Azimzadeh HR, Taleshi A. Heavy metal pollution in the floor dust of yazd battery repairing workshops in 2016. Iranian Journal of Health and Environment 2016; 9(1): 127-38. [In Persian].

37. Kleckerová A, Dočekalová H. Dandelion plants as a biomonitor of urban area contamination by heavy metals. Int J Environ Res 2014; 8(1): 157-64. doi: 10.22059/ ijer.2014.705.

38. Li FL, Liu CQ, Yang YG, Bi XY, Liu TZ, Zhao ZQ. Natural and anthropogenic lead in soils and vegetables around Guiyang city, southwest China: a $\mathrm{Pb}$ isotopic approach. Sci Total Environ 2012; 431: 339-47. doi: 10.1016/j. scitotenv.2012.05.040.

39. Dankoub Z, Ayoubi S, Khademi H, Lu SG. Spatial distribution of magnetic properties and selected heavy metals in calcareous soils as affected by land use in the Isfahan region, Central Iran. Pedosphere 2012; 22(1): 3347. doi: 10.1016/S1002-0160(11)60189-6.

40. Davashi L, Azimzadeh H. investigation on soil heavy metals pollution rate around Isfahan petroleum and refinery Industries near Ghameshlou wildlife refuge. Journal of Natural Environment 2015; 67(4): 403-14. [In Persian].

41. Zhu J, Fang L, Nie Z, Gao X. Ecological risk assessment of heavy metal in urban area soil. 4th International Conference on Bioinformatics and Biomedical Engineering; 2010 Jun 18-20; Chengdu, China: IEEE; 2010. doi: 10.1109/ ICBBE.2010.5516873.

42. Lu X, Wang L, Lei K, Huang J, Zhai Y. Contamination assessment of copper, lead, zinc, manganese and nickel in street dust of Baoji, NW China. J Hazard Mater 2009; 161(2-3): 1058-62. doi: 10.1016/j.jhazmat.2008.04.052.

43. Zhang J, Liu CL. Riverine composition and estuarine geochemistry of particulate metals in China--weathering features, anthropogenic impact and chemical fluxes. Estuar Coast Shelf Sci 2002; 54(6): 1051-70. doi: 10.1006/ ecss.2001.0879.

44. Taghipour M, Ayoubi S, Khademi H. Spatial variability of total $\mathrm{Ni}$ and $\mathrm{Cu}$ concentration in surface soils surrounding the Hamadan city using geostatistic technique. Journal of Water and Soil Conservation 2010; 17(2): 69-88. [In Persian].

45. Hakanson L. An ecological risk index for aquatic pollution control. A sedimentological approach. Water Res 1980; 14(8): 975-1001. doi: 10.1016/0043-1354(80)90143-8.

46. Bada BS, Olarinre TA. Characteristics of soils and heavy metal content of vegetation in oil spill impacted land in Nigeria. Soilsproceedings 2012; 1: 10-7. 
47. Rashki Ghaleno O, Sayadi MH, Rezaei MR. Potential ecological risk assessment of heavy metals in sediments of water reservoir case study: Chah Nimeh of Sistan. Proc Int Acad Ecol Environ Sci 2015; 5(4): 89-96.

48. Ogunkunle CO, Fatoba PO. Pollution loads and the ecological risk assessment of soil heavy metals around a mega cement factory in southwest Nigeria. Pol J Environ Stud 2013; 22(2): 487-93.

49. Sayadi MH, Shabani M, Ahmadpour N. Pollution index and ecological risk of heavy metals in the surface soils of
Amir-Abad area in Birjand city, Iran. Health Scope 2015; 4(1): e21137. doi: 10.17795/jhealthscope-21137.

50. Lebeau T, Braud A, Jezequel K. Performance of bioaugmentation-assisted phytoextraction applied to metal contaminated soils: a review. Environ Pollut 2008; 153(3): 497-522. doi: 10.1016/j.envpol.2007.09.015.

51. Zojaji F, Hassani AH, Sayadi MH. Bioaccumulation of chromium by Zea mays in wastewater-irrigated soil: an experimental study. Proc Int Acad Ecol Environ Sci 2014; $4(2): 62-7$. 